Dr Momčilo Grubač

profesor Pravnog fakulteta u Novom Sadu

\title{
NOVI ZAKONIK O KRIVIČNOM POSTUPKU RUSKE FEDERACIJE*
}

\section{I}

Posle desetogodišnjih priprema, u Ruskoj Federaciji je 18. decembra 2001. godine konačno donet novi Zakonik o krivičnom postupku. Zakonik je stupio na snagu 1. jula 2002. godine, osim nekoliko njegovih odredaba, za koje je predviđeno da će stupiti na snagu u drugim rokovima.

Novi Zakonik ,se rodio u vreme radikalnih promena, u mukama rastanka sa dugotrajnom domaćom krivično-pravosudnom praksom i u vreme opasnosti od kriminalizacije društva koja se nadvila nad Rusijom. Ovde su se sjedinila dva inače nespojiva političko-pravna i socijalno-psihološka fenomena: s jedne strane, novi zahtev da se pravosuđe liberalizuje, a sa druge, narastajući talas organizovanog i ekonomskog kriminala, kome se država i njene službe za zaštitu pravnog poretka slabo suprotstavljaju" (A. J. Saharev, u predgovoru Komentara Zakonika o krivičnom postupku Ruske Federacije, Moskva 2002).

Zakonik je donet, u prvom redu, zbog potrebe usaglašavanja krivičnog procesnog zakonodavstva sa odredbama novog Ustava Ruske Federacije (1993) koji je prvi put u ruskoj istoriji državu proglasio pravnom državom, a ljudska prava i slobode najvećim društvenim vrednostima. Sud je, prema tom Ustavu, dobio novu ulogu i novo mesto u hijerarhiji organa državne vlasti, tako da je vlast koja mu pripada postala ravnopravna sa ostalim granama državne vlasti. Tom konceptu novog Ustava nikako nije odgovarao do tada važeći ZKP RSFSR, iako je u toku svog četrdesetogodišnjeg trajanja modernizovan i usavršavan, izmenama i dopunama, više od četiri stotine puta (Saharev, str. VII).

* Rad primljen: 3. III 2003. 
Ruski autori ističu da je dobra strana Zakonika, pored ostalog, što je očuvao rukovodeću ulogu javnog tužioca u prethodnom postupku i, istovremeno, proširio kontrolnu funkciju suda u toj fazi postupka (Saharev, str. IX). Međutim, Zakonik se, prema tim mišljenjima, može i kritikovati. Prvo, on se mora posmatrati kao proizvod složenog procesa državnih i društvenih promena. Taj proces se pokazao kao izuzetno težak u državama koje tek započinju izgradnju demokratskog uređenja, jer su na njegovom početku greške skoro neizbežne. Proces promena je započet bez naučno pripremljenih programa i zbog toga je neizbežno krenuo spontano. Otuda potiču pojedina eklektična rešenja čije se posledice u početku ne mogu ni sagledati. Ne mala razočarenja donela su i neka rešenja nekritički preuzeta iz inostranog zakonodavstva ili potekla iz ,romantičarskih predstava" političara i pravnika koji stoje na čelu sudskih reformi. Pri tome, u mnogim sektorima obnovljenog zakonodavstva i primene prava nije $\mathrm{u}$ potpunosti uzeta $\mathrm{u}$ obzir ruska nacionalna specifičnost $\mathrm{i}$ bogato iskustvo domaće prakse i pravne misli (Saharev, str. X-XI). Posebno se kritikuje širenje principa akuzatornosti koje vodi pasivizaciji suda u poslu utvrđivanja istinitog činjeničnog stanja i izostavljanje odredaba koje su u ranijem sovjetskom ZKP ustanovljavale dužnost suda da preduzima određene mere usmerene na sprečavanje vršenja novih krivičnih dela, naročito u slučaju maloletnih delinkvenata (Saharev, str. XI-XII). Kritike se, dalje, odnose na sistematiku Zakonika, pravnotehničke nedostatke, složenost pojedinih odredaba, njihovu unutrašnju protivrečnost, neodređenost i nesaglasnost sa drugim federalnim zakonima (Saharev, str. XIII).

Kritike novog zakonodavstva treba prihvatati oprezno, jer mogu da budu preterane i da se i same zasnivaju na ličnim utiscima i davno stečenim navikama. Za objektivnu ocenu vrednosti novog zakonodavstva, ne samo u oblasti krivičnog procesnog prava, nego uopšte, naročito u zemljama koje radikalno menjaju svoj pravni sistem, potrebno je da prođe određeno vreme, jedan adaptacioni period u kome će primenjivači prava, u prvom redu, i sami usvojiti zakon, navići se na njega i pravilno shvatiti njegovu logiku. Naravno, neke greške se mogu i odmah uočiti i ispraviti. I sami kritičari novog Zakonika su potpuno svesni nužnosti da se on bez kolebanja sprovede. Zabrinutost primenjivača prava zbog nesavršenosti zakona može se shvatiti, ali ne i opravdati, jer savršenih zakona nema. Samo buduća praksa može da pokaže stvarnu vrednost i životnu sposobnost pravnih ustanova i rešenja novog ZKP RF (Saharev, str. XIII).

\section{II}

Novi Zakonik ima pet delova: „Opšte odredbe”, „Predsudski postupak”, „Sudski postupak”, „Posebni sudski postupci” i "Međunarodna saradnja u krivičnom postupku". Svaki deo Zakonika sadrži po nekoliko odeljaka, koji se dalje dele na glave. Navešćemo ih ovde kako su dati u Zakoniku bez komentara. 
Deo prvi („Opšte odredbe”) ima šest odeljaka: I. Osnovne odredbe (sadrži glave: 1. Krivično procesno zakonodavstvo, 2. Principi krivičnog postupka, 3. Krivično gonjenje, 4. Osnovi za odbijanje zahteva za pokretanje postupka, obustavu postupka i krivičnog gonjenja); - II. Učesnici krivičnog postupka (glave: 5. Sud, 6. Učesnici krivičnog postupka na strani optužbe, 7. Učesnici krivičnog postupka na strani odbrane, 8. Drugi učesnici krivičnog postupka, 9. Okolnosti koje isključuju učešće u krivičnom postupku); - III. Dokazi i dokazivanje (glave: 10. Dokazi u krivičnom postupku, 11. Dokazivanje); - IV. Mere procesne prinude (glave: 12. Zadržavanje osumnjičenog, 13. Mere sprečavanja, 14. Druge mere procesne prinude); - V. Molbe $i$ žalbe (glave: 15. Molbe, 16. Žalbe protiv radnji i odluka suda i službenih lica u krivičnom postupku); - VI. Druge odredbe (glave: 17. Procesni rokovi. Troškovi postupka, 18. Rehabilitacija).

Deo drugi (,Predsudski postupak”) ima dva odeljka: VII. Pokretanje krivičnog postupka (glave: 19. Povodi i osnovi za pokretanje krivičnog postupka, 20. Režim pokretanja krivičnog postupka); - VIII. Prethodno istraživanje (glave: 21. Opšti uslovi prethodnog istraživanja, 22. Prethodni izviđaji, 23. Pozivanje u svojstvu okrivljenog. Stavljanje pod optužbu, 24. Uviđaj. Pregled. Izviđajni eksperiment, 25. Pretresanje. Oduzimanje stvari i dokumenata. Zaplena poštanskih i telegrafskih pošiljki. Kontrola i registracija razgovora, 26. Ispitivanje. Suočavanje. Prepoznavanje. Proveravanje iskaza, 27. Izvođenje sudskog veštačenja, 28. Prekidanje i nastavljanje prethodnog izviđanja, 29. Obustava krivičnog postupka, 30. Upućivanje krivične stvari sa optužnim predlogom javnom tužiocu, 31. Radnje i odluke javnog tužioca, 32. Istraga).

Deo treći („Sudski postupak”) ima sedam odeljaka: IX. Postupak $u$ sudu prvog stepena (glave: 33. Opšti postupak pripremanja sudskog zasedanja, 34. Prethodno ročište, 35. Opšti uslovi za sudski pretres, 36. Pripremanje sudskog zasedanja, 37. Sudska istraživanja (dokazni postupak), 38. Raspravljanje stranaka i završna reč okrivljenog, 39. Izricanje presude; - X. Posebne odredbe o sudskom pretresu (glava: 40. Posebne odredbe o donošenju sudske odluke u slučaju saglasnosti okrivljenog sa podignutom optužbom); - XI. Specifičnosti postupka pred mirovnim sudom (glava: 41. Postupak za dela iz nadležnosti mirovnog suda); - XII. Posebnosti postupka pred porotnim sudom (glava: 42. Postupak po krivičnim delima koja se pretresaju uz učešće sudija porotnika); - XIII. Postupak $u$ sudu drugog stepena (glave: 43. Apelaciona i kasaciona žalba protiv nepravnosnažnih sudskih odluka, 44. Apelacioni postupak, 45. Kasacioni postupak); - XIV. Izvršenje presude (glave: 46. Naređivanje izvršenja presude, rešenja i naredbe, 47. Rešavanje pitanja vezanih za izvršenje presude); $-X V$. Ispitivanje pravnosnažnih presuda, rešenja $i$ naredaba (glave: 48. Postupak u nadzornoj instanci, 49. Ponavljanje krivičnog postupka na osnovu novih ili novootkrivanih okolnosti).

Deo četvrti („Posebni sudski postupci”) ima dva odeljka: XVI. Specifičnosti postupka za pojedine kategorije krivičnih dela (glave: 50. Po- 
stupak za krivična dela maloletnika, 51. Postupak za primenu prinudnih medicinskih mera); - XVII. Posebnosti postupka za krivična dela određenih lica (glava: 52. Specifičnosti postupka za krivična dela određenih lica - članova Saveta Federacije, poslanika u Državnoj dumi i drugih poslanika, sudija Ustavnog suda i drugih sudija, predsednika i kandidata za predsednika Federacije, javnog tužioca, islednika i advokata - član 447. ZKP).

Deo peti (,Međunarodna saradnja u krivičnom postupku”) ima jedan odeljak: XVIII. Postupak saradnje suda, javnog tužioca, islednih $i$ istražnih organa sa odgovarajućim organima $i$ službenim licima stranih država $i$ međunarodnih organizacija, i tri glave: 53. Osnovne odredbe o postupku saradnje sudova, tužilaca, islednika i organa istrage sa odgovarajućim organima i službenim licima inostranih država i međunarodnih organizacija, 54. Izručenje okrivljenih i osuđenih lica, 55. Predaja lica osuđenih na kazne lišenja slobode radi izdržavanja kazne u zemlji čiji su državljani.

\section{III}

Da bi naš čitalac stekao nešto potpuniju predstavu o novom ruskom ZKP, prikazaćemo sada detaljnije njegove odredbe koje se odnose na mere procesne prinude (čl. 91-118), mada u brojnim članovima Zakonika (ukupno ih ima 473) postoji i mnogo drugih interesantnih i originalnih rešenja koja zaslužuju pažnju.

Zakonik predviđa dve vrste mera procesne prinude: prema osumnjičenom i prema okrivljenom.

1. Prema licu koje je osumnjičeno da je izvršilo krivično delo za koje može biti izrečena kazna lišenja slobode može biti određeno zadržavanje u trajanju od 48 časova, pod daljim uslovom, da je to lice zatečeno pri izvršenju krivičnog dela ili neposredno posle izvršenja, ili da su oštećeni ili očevidci na njega ukazali kao na učinioca krivičnog dela, ili da su na njemu, kod njega, na njegovoj odeći ili u njegovom stanu otkriveni očigledni tragovi krivičnog dela. Osim toga, zadržavanje može biti određeno i prema licu koje je osumnjičeno po nekom drugom osnovu, ako pokuša da se sakrije, ili nema stalno boravište, ili se ne može utvrditi njegov identitet, ili ako je javni tužilac, odnosno istražitelj ili islednik uz saglasnost javnog tužioca, podneo sudu zahtev za određivanje pritvora. Zadržavanje određuje organ predsudskog postupka (istražitelj ili islednik) ili javni tužilac. O zadržavanju se ne donosi nikakva odluka (dakle, žalba je isključena), već se sastavlja zapisnik, najkasnije u roku od tri sata od privođenja osumnjičenog nadležnom organu. Osumnjičeni se poučava o pravima koja su u članu 46. stav 4. predviđena za svakog osumnjičenog: da mu se saopšti zašto je osumnjičen, da može dobiti kopiju zapisnika o zadržavanju, da može dati ili uskratiti iskaz, da može uzeti branioca i da se pre prvog ispitivanja sa njim može sastati nasamo i poverljivo, da može 
predlagati dokaze, podnositi zahteve i opozive, služiti se svojim jezikom ili jezikom kojim vlada, koristiti besplatne usluge prevodioca, razgledati zapisnike o istražnim radnjama u kojima je učestvovao i stavljati na njih primedbe, da po dozvoli organa predsudskog postupka može učestvovati u izvođenju istražnih radnji koje se preduzimaju po njegovom zahtevu ili po zahtevu njegovog branioca odnosno zakonskog zastupnika, da može podnositi žalbe protiv radnji (ili nečinjenja) i odluka suda, javnog tužioca i organa prethodnog postupka i da se može braniti svim drugim sredstvima i na sve druge načine koje Zakonik ne zabranjuje. - U zapisnik o zadržavanju unose se podaci o vremenu njegovog sastavljanja, vremenu, mestu, osnovu i razlozima zadržavanja, rezultatima pretresanja osumnjičenog i drugim okolnostima slučaja. Zapisnik potpisuje lice koje ga je sastavilo i osumnjičeni. O zadržavanju koje je odredio isledni organ ili istražitelj pismeno se obaveštava javni tužilac u roku od 12 časova. Osumnjičeni se mora ispitati najkasnije za 24 sata od početka zadržavanja. Zadržano lice se mora osloboditi ako po isteku 48 sati prema njemu ne bude određen pritvor. - O zadržavanju osumnjičenog se moraju obavestiti njegovi bliski srodnici, najkasnije u roku od 12 sati od kad je određeno zadržavanje, a ako je u pitanju vojno lice ili strani državljanin, obaveštava se komanda vojne jedinice osumnjičenog, odnosno ambasada ili konzulat njegove države. Izuzetno, ako to zahtevaju interesi prethodnog postupka ili interesi čuvanja tajne, ova obaveštavanja mogu izostati, pod uslovom da se sa tim saglasi javni tužilac, ali ne i u slučaju ako je osumnjičeni maloletnik.

2. Prema okrivljenom se mogu primeniti tzv. mere sprečavanja (presečenija). To su: 1) potpisano obećanje da neće napustiti mesto boravišta, 2) lično jemstvo, 3) nadzor komande vojne jedinice, 4) kontrola maloletnika, 5) kaucija, 6) kućni zatvor i 7) pritvor. Ove mere se mogu primeniti prema okrivljenom, tj. licu prema kome je određenim aktom organa prethodnog postupka ili suda pokrenut krivični postupak, a izuzetno i prema osumnjičenom (član 100), ali tada se mera mora ukinuti ako akt o pokretanju krivičnog postupka ne bude donet i dostavljen osumnjičenom u roku od deset dana od kad je mera primenjena. Posebni uslovi za primenu mera su: da se okrivljeni krije, da postoji mogućnost da nastavi da vrši krivična dela ili opasnost da ugrozi svedoka ili drugog učesnika postupka, da uništi dokaze ili da na drugi način ometa krivični postupak (član 97. stav 1. tač. 1-3). Mere se .mogu naložiti i radi obezbeđenja izvršenja presude (član 97. stav 2). Mere određuje islednik, istražitelj, javni tužilac ili sudija rešenjem, protiv kojeg se može izjaviti žalba.

Davanje obećanja da neće napustiti boravište bez dozvole organa prethodnog postupka, javnog tužioca ili suda praćeno je ustanovljavanjem dalje dužnosti okrivljenog da se uredno javlja tim organima kadgod ga pozovu i zabranom da na drugi način sprečava tok krivičnog postupka (član 102). - Lično jemstvo predstavlja pismenu garanciju trećeg lica koje zaslužuje poverenje da okrivljeni neće napustiti boravište bez dozvole nadležnog organa, da će se odazivati pozivima i da na drugi način neće 
ometati krivični postupak. Ako ne vrši preuzete obaveze jemac se može novčano kazniti (član 103). - Nadzor komande vojne jedinice može se, uz saglasnost okrivljenog, odrediti prema okrivljenom koji je vojno lice ili vojni službenik. Nadzor treba da obezbedi da okrivljeni ne napusti mesto boravišta, da se javlja na pozive istražnih i sudskih organa i da na drugi način ne ometa postupak (član 104). - Kontrola okrivljenih maloletnika poverava se roditeljima, staraocima ili drugim licima od poverenja, kao i pojedincima iz specijalnih dečjih ustanova u kojima se maloletnik nalazi. Ta lica se pismeno obavezuju da maloletnik neće napustiti mesto prebivališta, da će se odazivati pozivima organa prethodnog postupka i suda i da neće ometati krivični postupak. Kao i jemci, ta lica mogu biti novčano kažnjena ako ne ispune preuzete obaveze (član 105). - Kaucija je ono što se u našem procesnom pravu razume kao stvarno jemstvo i sastoji se u polaganju novca, hartija od vrednosti ili dragocenosti od strane okrivljenog ili drugih fizičkih ili pravnih lica sa ciljem da se obezbedi da će se okrivljeni uredno odazivati pozivu nadležnih organa i da neće vršiti nova krivična dela. Ovim jemstvom se može zameniti već određeni krućni zatvor ili pritvor (član 106). - Kućni zatvor se sastoji u ograničenju slobode kretanja okrivljenog i u zabrani da se sastaje sa određenim licima, da prima ili odašilje pošiljke i da vodi razgovore bilo kojim sredstvima komuniciranja. Ovu meru može da odredi samo sud pod uslovima i u postupku koji su predviđeni za određivanje pritvora. Pri određivanju kućnog zatvora sud uzima u obzir uzrast okrivljenog, njegovo zdravstveno stanje, porodične prilike i druge okolnosti. U rešenju kojim se nalaže kućni zatvor određuje se organ ili službeno lice koji će nadzirati ispunjenje određenih ograničenja (član 107).

Pritvor je najstrožija mera procesne prinude. U novom Zakoniku je uređen sa dva velika člana (108. i 109) koji zajedno imaju 24 stava. Pritvor se može odrediti samo sudskim rešenjem za krivična dela za koja je predviđena kazna lišenja slobode preko dve godine, a izuzetno i ako je propisana blaža kazna (ako okrivljeni nema prebivalište u Rusiji, ako se ne može identifikovati, ako je prekršio ranije izrečenu blažu meru obezbeđenja ili se krije). Prema maloletniku pritvor može biti određen samo za teška ili osobito teška krivična dela, a izuzetno i za dela srednje težine. Postupak određivanja pritvora teče tako što javni tužilac ili drugi organ prethodnog postupka (islednik ili istražitelj), uz saglasnost javnog tužioca, podnosi sudu obrazložen i dokumentovan zahtev. O zahtevu odlučuje sudija pojedinac nadležnog suda na ročištu o kome se obaveštavaju okrivljeni, javni tužilac i branilac, ako ga u postupku ima. Zasedanju mogu prisustvovati i zakonski zastupnici maloletnika i islednik ili istražitelj. Ročište se mora održati u toku osam sati od prijema zahteva. Nedolazak obaveštenih lica ne sprečava razmatranje zahteva, izuzev kad je reč o odsustvu okrivljenog. U odsustvu okrivljenog sudija može doneti rešenje o pritvoru samo ako je protiv njega raspisana međunarodna poternica. Zahtev može biti usvojen rešenjem kojim se pritvor određuje, ili odbijen, ili odluka o njemu odložena za 72 sata radi podnošenja dopunskih dokaza o 
osnovanosti pritvora. Posle odbijanja, novi zahtev prema istom licu i za isto krivično delo može se podneti samo ako se jave nove okolnosti u pri$\log$ osnovanosti pritvora. Zalba protiv rešenja o određivanju pritvora ne zadržava izvršenje, a podnosi se višem sudu u roku od tri dana od donošenja rešenja. Viši sud je dužan da o žalbi odluči za tri dana od prijema. O stavljanju okrivljenog u pritvor odmah se obaveštavaju njegovi bliski srodnici. Sudija koji odlučuje o pritvoru nije isti za sve slučajeve, već se menja u skladu sa pravilima o raspodeli poslova na sve sudije nadležnog suda (član 108. stav 13). - Pritvor u istrazi može trajati dva meseca. Ako se prethodni postupak ne može završiti u tom roku i ako nema osnova da pritvor bude zamenjen drugom merom procesne prinude, sudija ga može produžiti na vreme do šest meseci po zahtevu javnog tužioca ili drugog organa prethodnog postupka uz saglasnost javnog tužioca. Ako su u pitanju teška i osobito teška krivična dela i samo u slučaju naročite složenosti predmeta, pritvor može biti dalje produžen do 12 meseci po zahtevu istražitelja koji se podnosi uz saglasnost javnog tužioca članice $\mathrm{Fe}$ deracije. Po isteku 12 meseci, pritvor može biti produžen do 18 meseci u izuzetnim slučajevima, samo prema licu koje je okrivljeno za izuzetno teško krivično delo, po zahtevu istražitelja i uz saglasnost Generalnog javnog tužioca Federacije. Dalje produženje pritvora u prethodnom postupku nije dozvoljeno. - Materijal okončane istrage mora biti predočen pritvorenom okrivljeniku i njegovom braniocu najkasnije 30 dana pre isteka roka najdužeg trajanja pritvora (šest, 12, 18 meseci), i to je uslov da okrivljeni ostane u pritvoru i u toku daljeg postupka. Ako okrivljeni i njegov branilac nisu upoznati sa spisima okončane istrage u roku od 30 dana pre isteka pritvora već kasnije, okrivljeni se ima pustiti na slobodu odmah po isteku vremena za koje je određen pritvor.

3. Zakonik sadrži još i posebnu glavu o ,drugim merama procesne prinude" (čl. 111-118). Te mere prema osumnjičenom ili okrivljenom (neke i prema svedoku i oštećenom) primenjuju organi prethodnog postupka (javni tužilac, islednik ili istražitelj) ili sud na njihov zahtev ili samostalno, da bi se obezbedio nesmetan tok postupka ili izvršenje izrečene presude. To su: a) pismeno obavezivanje na uredno odazivanje pozivima nadležnih organa i obaveštavanje o eventualnoj promeni adrese (može se naložiti i oštećenom i svedoku) - član 112 ; - b) privođenje - član 113 ; - v) privremeno udaljenje službenog lica od vršenja službene dužnosti (meru može izreći samo sud na zahtev organa prethodnog postupka) - član $114 ;$ - g) zaplena imovine, uključujući i hartije od vrednosti i novčana sredstva na bankarskim računima, radi obezbeđenja imovinskopravnog zahteva, drugih imovinskih potraživanja i izvršenja kazne konfiskacije imovine ako je moguće da bude izrečena (meru određuje sud na posebnom ročištu po zahtevu javnog tužioca ili drugog organa prethodnog postupka) - čl. 115. i 116; d) novčano kažnjavanje (čl. 117. i 118), kome ne podležu osumnjičeni, okrivljeni i branilac. I ovu meru može izreći samo sud, pa i kad se odnosi na radnje koje se preduzimaju u prethodnom postupku od nesudskih organa (tada se mera izriče na zahtev organa prethodnog postupka na posebnom sudskom ročištu). 